\title{
Cytomegalovirus infection of the cervix detected by cytology and histology: a report of five cases
}

\author{
J. C. HUANG AND B. NAYLOR \\ Department of Pathology, The University of Michigan, Ann Arbor, MI, USA
}

Accepted for publication 12 March 1993

HUANG J. C. AND NAYLOR B. (1993) Cytopathology 4, 237-241

\section{Cytomegalovirus infection of the cervix detected by cytology and histology: a report of five cases}

We present four cases of cytomegalovirus (CMV) infection detected by cervical cytology of asymptomatic young women. One patient who had undergone bone marrow transplantation was immunosuppressed, but no factors predisposing to CMV infection were identified in the other three patients. A cervical biopsy specimen from a fifth patient, who was also asymptomatic, demonstrated the locus of CMV infection to be in endocervical gland cells. Immunocytochemical and polymerase chain reaction studies on this biopsy specimen confirmed that the histological changes were caused by CMV. The finding of CMVinfected cells in cervical cytological or biopsy specimens is a rarity. Our observations in asymptomatic, non-immunocompromised women suggest their presence is an incidental finding, unlikely to have any clinical significance.

Keywords: cytomegalovirus, uterine cervix, cytopathology

Nous présentons 4 cas d'infection à cytomégalovirus (CMV) détectés par cytologie cervico-utérine chez des jeunes femmes asymptomatiques. Une patiente ayant subi une greffe de moelle osseuse était immuno-déprimée, mais aucun facteur prédisposant à l'infection CMV n'a été retrouvé chez les trois autres patientes. Une cinquième patiente asymptomatique présentait, sur une biopsie cervicale, un foyer d'infection à $\mathrm{CMV}$ dans les cellules glandulaires endocervicales. Les études immunocytochimiques et par PCR de cet échantillon ont confirmé que les modifications histologiques étaient produits par CMV. La découverte de cellules infectées par CMV dans des prélèvements cytologiques ou histologiques du col utérin est très rare. Nos observations chez des femmes asymptomatiques, non immunodéprimées suggèrent que ces découvertes sont fortuites, probablement sans signification clinique.

Berichtet wird über 4 Fälle von Cytomegalievirus (CMV)-Infektion, die in Cervikalabstrichen asymptomatischer junger Frauen nachgewiesen wurde. Nur eine dieser Patientinnen war nach einer Knochenmarkstransplantation immun-supprimiert. Eine Cervixbiopsie der 5, asymptomatischen Patientin ergab eine CMV-Infektion in den endocervikalen Drüsenzellen. Dies konnte immunocytochemisch und durch die Polymerasekettenreaktion bestätigt werden. Der Nachweis von CMVinfizierten Fällen in cytologischen oder histologischen Cervixpräparaten ist selten. Unsere Beobachtung bei asymptomatischen nicht immunkompromittierten Frauen zeigt, daß es sich um zufällige Feststellungen ohne klinische Bedeutung handelt. 


\section{INTRODUCTION}

Cytomegalovirus (CMV) infection of the uterine cervix is rarely detected. Although case reports of CMV infection diagnosed by cervical cytology or histology have been published $^{1-4}$, most of the studies on maternal and congenital CMV infection have used the results of viral cultures and serology as evidence of infection ${ }^{5-7}$. In this paper we report four cases of cervical CMV infection diagnosed by cytology in our cytopathology laboratory over a 32-year period, between 1960 and 1992. Two of these cytological specimens were in our routine screening material, and two were received in consultation. In corroboration of our cytological findings, we illustrate a cervical biopsy specimen that confirms previous observations that the locus of infection is in endocervical gland cells ${ }^{8}$.

\section{PATIENTS AND METHODS}

The four cytological specimens consisted of Papanicolaou-stained cervical smears. Clinical information and available follow up were obtained from the patients' records or health care providers. The patients' ages ranged from 20 to 32 years. None of the four patients had any gynaecological symptoms, and pelvic examination did not reveal any abnormality except for patient 1 . Her examination was reported as 'consistent with bacterial vaginosis'; gonococcal and chlamydial cultures, however, were negative. Only patient 1 had a history of sexually transmitted disease: gonorrhoea 3 years before her diagnostic smear. The cervical smear of only patient 1 was obtained in relationship to pregnancy, having been prepared 6 weeks post partum.

Except for patient 4, all of these patients were generally in good health, with no evidence of immunosuppression at the time of examination. Patient 4 had undergone bone marrow transplantation for chronic myelogenous leukaemia 3 months before her diagnostic cervical smear.

Patient 5 underwent cervical biopsy because of a cytological diagnosis of slight cervical squamous epithelial dysplasia. She had no symptoms, and clinical examination was normal. Because the biopsy specimen showed no evidence of dysplasia, the clinician requested it be sent to us in consultation.

The biopsy specimen was stained with haematoxylin and eosin. Immunohistochemical staining for CMV was performed on the specimen by the avidin-biotin peroxidase method. The polymerase chain reaction (PCR) was also performed to detect the presence of CMV DNA, in particular the major immediate early (MIE) and late antigen (LA) genes.

Table 1 summarizes the clinical aspects of the five patients.

\section{RESULTS}

The cervical smears of patients 1-4 demonstrated large epithelial cells, each with a large single nucleus containing a prominent eosinophilic inclusion surrounded by a clear halo. The cytoplasm of these cells also contained numerous small basophilic inclusions (Figure 1). The number of CMV-infected cells in the cervical smears ranged from 1 to 13. Any cells attached to the CMV-infected cells appeared to be endocervical gland cells. Otherwise, these smears showed no abnormality.

In addition to the specific changes of CMV infection in endocervical gland cells in the biopsy specimen (Figure 2) of patient 5, the endocervical stroma contained plasma cells 
Table 1. Clinical aspects of cytomegalovirus (CMV)-infected patients

\begin{tabular}{llllll}
\hline Patient & $\begin{array}{l}\text { Age, } \\
\text { years }\end{array}$ & $\begin{array}{l}\text { Appearance of } \\
\text { cervix/vagina }\end{array}$ & Immunosuppressed & STD & Post-partum \\
\hline 1 & 25 & 'Bacterial vaginosis' & No & Gonorrhoea & Yes \\
2 & 21 & Normal & No & No & No \\
3 & 20 & Normal & No & Not known & No \\
4 & 32 & Normal & Yes & No & No \\
5 & 23 & Normal & No & No & No \\
\hline
\end{tabular}

STD, Sexually transmitted disease.
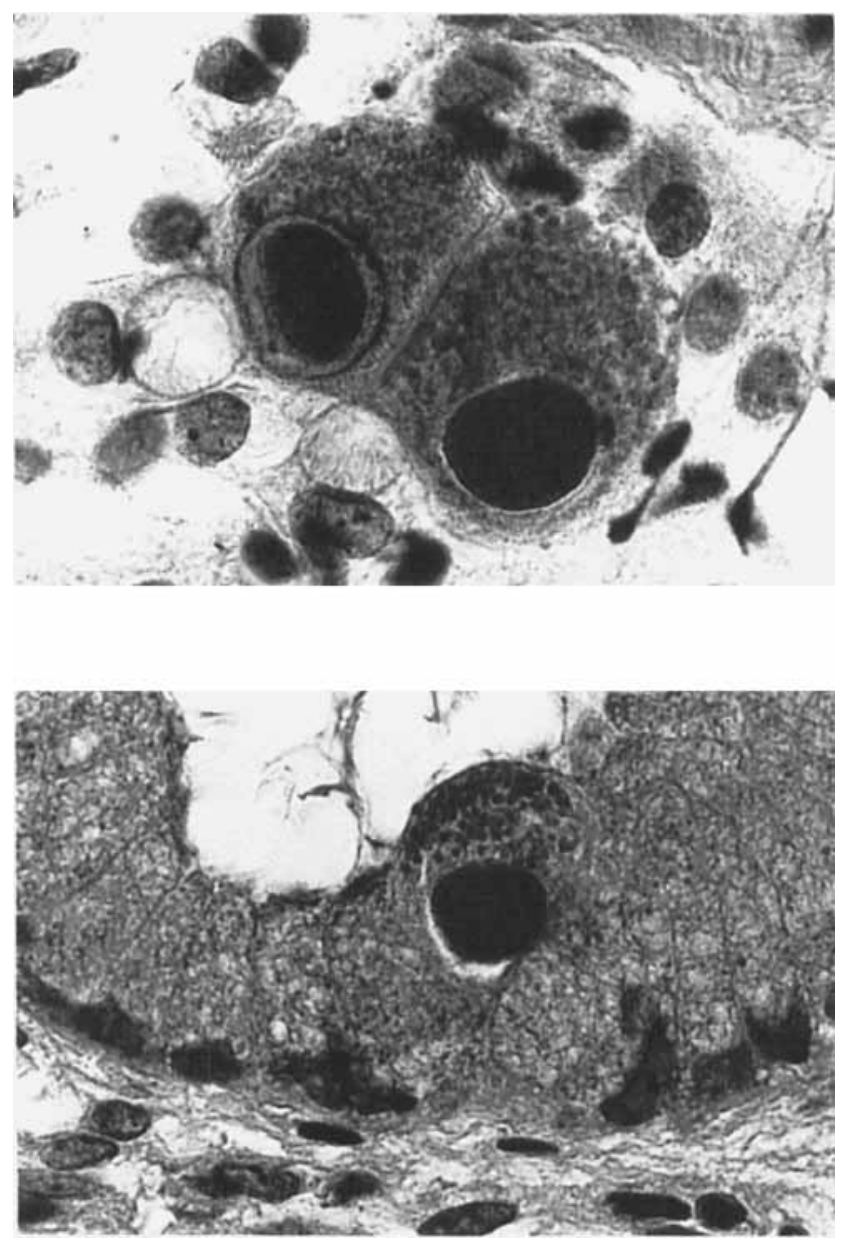

Figure 1, Cervical smear. Two epithelial cells illustrating the nuclear and cytoplasmic inclusions characteristic of cytomegalovirus (CMV) infection. Papanicolaou $\times 825$.
Figure 2. Endocervical biopsy specimen. Endocervical gland cell demonstrating cytomegalovirus (CMV) infection. $\mathrm{H} \& \mathrm{E} \times 528$.

consistent with chronic inflammation. This specimen did not show squamous epithelial dysplasia. Immunocytochemical staining gave a positive reaction for $\mathrm{CMV}$ in the infected endocervical gland cells. PCR demonstrated two CMV-associated genes: MIE and LA. 


\section{DISCUSSION}

CMV infections, almost always asymptomatic, are most likely to be clinically important in the following situations: congenital infection, organ transplantation, and any other situation in which a patient is immunosuppressed. After a primary infection, the virus may be shed through tears, saliva, urine, breast milk, cervical secretion or semen, and thereby be transmitted to other individuals. The virus may then persist in a dormant state; reactivation of the virus may occur, with immunosuppression being a major predisposing factor. Pregnancy has also been postulated to reactivate the virus by hormonal stimuli, with a reported prevalence of $\mathrm{CMV}$ excretion in urine or cervical secretion during pregnancy of $11-12 \% \%^{5,7}$.

We cannot ascertain whether the CMV infection in these five women represents primary infection or reactivation. Only patient 4 was immunosuppressed, which could account for possible reactivation of infection. The cervical smear of patient 1 was prepared 6 weeks post partum. The baby was apparently normal; perhaps the infant was not infected. On the other hand, not all infants with congenital CMV infection display clinical evidence of infection ${ }^{6}$. Jordan and colleagues ${ }^{9}$ found a higher prevalence of cervical CMV infection in non-pregnant women who have had a previous or current gonococcal infection. The previous history of gonorrhoea in patient 1 lends further support to that observation.

The sensitivity of cytology for detecting CMV infection of the cervix is lower than that of viral culture. In a study of 145 patients attending a sexually transmitted disease clinic in London, UK, 12 had positive cultures for CMV, but only one of these 12 culture-positive patients had a CMV-positive cervical smear ${ }^{10}$. A screen of 244 pregnant women in Helsinki, Finland, resulted in four cervical cultures positive for CMV; however, cervical smears, including repeat smears, from all four women were negative for $\mathrm{CMV}^{11}$.

Since CMV pneumonitis has become the most common infectious cause of death in allogeneic bone marrow transplant recipients ${ }^{12}$, the ability rapidly and accurately to diagnose CMV infections has assumed great importance. Viral culture requires at least 2-3 weeks for results, and cytological and histological examinations are not very sensitive. Immunohistochemical methods, in situ hybridization, and PCR have been applied in an attempt to increase the sensitivity and speed of detection of CMV infection.

The presence of CMV-infected endocervical gland cells in a cervical smear is rare and very striking. Its rarity is attested to by the low prevalence of such smears in our routine screening specimens: only two examples in 32 years, during which we examined about 700000 cervicovaginal smears. All of the five women in this report were asymptomatic, and none received any treatment for the condition. Furthermore, no additional studies, such as CMV antibody titres, or follow up related to the CMV infection, were considered necessary and were not carried out.

Reports of CMV cervicitis in at least two patients with AIDS have been published ${ }^{13,14}$. Both patients had gynaecological symptoms, and histopathological examination of the cervix revealed widespread infection by CMV. Long-term follow up was not available for one patient, but the other died from 'AIDS-related disease' 6 months after the detection of CMV infection of her genital tract.

Some investigators have postulated that the incidence of CMV inclusions in cervical cytological specimens will increase as the AIDS epidemic continues ${ }^{15}$. From our series of five patients and review of the literature, it appears that the presence of endocervical gland cells manifesting CMV infection in cervical smears is unlikely to be of any clinical 
significance in asymptomatic, healthy women. However, the finding of CMV-infected cells in cervical smears from immunocompromised women with gynaecological symptoms is probably significant, especially if the infection is widespread.

\section{REFERENCES}

1 Gideon K, Zaharopoulos P. Cytomegalovirus endocervicitis diagnosed by cervical smear. Diagn Cytopathol 1991; 7: 625-7.

2 Ross L. Incidental finding of cytomegalovirus inclusions in cervical glands. A case report. $A m J$ Obstet Gynecol 1966; 95: 956-8.

3 Wenckebach GFC, Curry B. Cytomegalovirus infection of the female genital tract. Histologic findings in three cases and review of the literature. Arch Pathol Lab Med 1976; 100: 609-12.

4 Zhao Y-T. Cytomegalovirus infection of the uterine cervix. Report of 2 cases. Chin Med J (Engl) 1982; 95: 467-8.

5 Montgomery R. Youngblood L, Medearis DN. Recovery of cytomegalovirus from the cervix in pregnancy. Pediatrics 1972; 49: 524-31.

6 Nankervis GA, Kumar ML, Cox FE, Gold E. A prospective study of maternal cytomegalovirus infection and its effect on the fetus. Am J Obstet Gynecol 1984; 149: 435-40.

7 Reynolds DW, Stagno S, Hosty TS, Tiller M, Alford CA. Maternal cytomegalovirus excretion and perinatal infection. $N$ Engl $J$ Med 1973; 289: $1-5$.

8 Gupta PK. Microbiology, inflammation and viral infections. In: Bibbo M, ed. Comprehensive Cytopathology. Philadelphia: WB Saunders, 1991: 132.
9 Jordan MC, Rousseau WE, Noble GR, Stewart JA, Chin TDY. Association of cervical cytomegaloviruses with venereal disease. $N$ Engl J Med 1973; 288: $932-4$.

10 Morse AR, Coleman DV, Gardner SD. An evaluation of cytology in the diagnosis of herpes simplex virus infection and cytomegalovirus infection of the cervix uteri. J Obstet Gynaecol Br Commonw 1974; 81: 393-8.

11 Vesterinen E, Savolainen E-R, Purola E, Saksela E, Leinikki $P$. Occurrence of genital herpes simplex and cytomegalovirus infections in pregnancy. Acta Obstet Gynecol Scand 1977; 56: 101-4.

12 Erice A. Diagnosis of cytomegalovirus pneumonitis after bone marrow transplantation. Is PCR the answer? Am J Clin Pathol 1991; 96: 564-7.

13 Brown S, Senekjian EK, Montag AG. Cytomegalovirus infection of the uterine cervix in a patient with acquired immunodeficiency syndrome. Obstet Gynecol 1988; 71: 489-91.

14 Sickel JZ, Rutkowski MA, Bonfiglio TA. Cytomegalovirus inclusions in routine cervical Papanicolaou smears: a clinicopathologic study of three cases (Abstr.) Acta Cytol 1991; 35: 646.

15 Henry-Stanley MJ, Stanley MW, Horwitz CA. Cytologic diagnosis of cytomegalovirus in cervical smears (Abstr.). Acta Cytol 1992; 36: 604-5.

\section{ADDENDUM}

Since submitting this manuscript we have received a cervical smear from a 13-year-old girl who complained of irregular menses since her heart transplant 6 months previously for hypertrophic cardiomyopathy. Gynaecological examination did not reveal any abnormality; her cervical smear, however, contained 57 epithelial cells showing the nuclear and cytoplasmic inclusions characteristic of CMV infection. Although the patient was serologically CMV-positive at the time of transplantation and received a heart from a CMV-positive donor, she had been receiving ganciclovir prophylactically. No change has been made in her therapy as a result of the cytological finding. 